\section{Spermatogenic and Haematological effects of Aqueous and Ethanolic Extracts of Hymenocardia acida Stem Bark on Aluminium-Induced Toxicity in Male Wistar Rats}

\section{Abstract}

This study was designed to determine the spermatogenic and haematological effects of aqueous and ethanolic stem bark extracts of Hymenocardia acida on Aluminium chloride-induced toxicity in male wistar rats. Thirty male albino Wistar rats were used and toxicity was induced using $100 \mathrm{mg} / \mathrm{kg}$ body weight (bw) $\mathrm{AlCl}_{3}$. The rats were distributed into six groups of five rats each. The drug and extract administration lasted for seven days, thereafter the animals sacrificed. The results indicated that oral dose of $100 \mathrm{mg} / \mathrm{kg}$ bw extracts of $H$. acida did not show any significant $(p>0.05)$ change in testosterone levels when compared with both normal and negative control. Ethanolic extract showed non-significant ( $p>0.05$ ) increase on Luteinizing hormone (LH) when compared with both normal and negative control group. Administration of $\mathrm{AlCl}_{3}$ caused a significant $(p<0.05)$ decrease in Follicle Stimulating Hormone (FSH), while the plants extracts caused a non-significant increase when compared with the negative control. Thiobarbituric Acid Reactive Substance (TBARS) increased significantly $(p<0.05)$ in negative control, but decreased significantly in groups treated with aqueous and ethanolic extract of $\mathrm{H}$. acida when compared with the negative control. Induction of $\mathrm{AlCl}_{3}$ toxicity caused a non-significant ( $p>0.05$ ) alterations of most of the haematological parameters evaluated, but administration of the plant extracts was able to mildly ameliorate these effects (especially on RBC and $\mathrm{Hb}$ ). The result of this study shows $\mathrm{AlCl}_{3}$ toxicity causes alterations of $\mathrm{LH}, \mathrm{FSH}$ and TBARS, but aqueous and ethanolic stem bark extracts of $\mathrm{H}$. acida may possibly ameliorate the alteration. $\mathrm{Also}, \mathrm{AlCl}_{3}-$ toxicity mildly influences the synthesis of certain haematological indices, but the extracts may modulate some of this interference.

Keywords: Albino rats; Aluminium chloride toxicity; Aqueous and ethanolic extract; Hymenocardia acida; Spermertogenic

\section{Yakulbu OE ${ }^{1}$, Nwodo OFC ${ }^{2}$,} Imo $\mathrm{C}^{1}$ and Ogwoni $\mathrm{HA}^{1}$

\author{
Department of Biochemistry, Faculty \\ of Pure and Applied Sciences, Federal \\ University, Wukari, Nigeria \\ 2 Department of Biochemistry, Faculty of \\ Biological Sciences, University of Nigeria, \\ Nsukka, Nigeria
}

Corresponding author: Ojochenemi E. Yakubu,

\section{oj4real_2007@yahoo.co.uk}

Department of Biochemistry, Faculty of Pure and Applied Sciences, Federal University, Wukari, Nigeria.

\section{Tel: 2348069078726}

Citation: Yakubu OE, Nwodo OFC, Imo C, et al. Spermatogenic and Haematological effects of Aqueous and Ethanolic Extracts of Hymenocardia acida Stem Bark on AluminiumInduced Toxicity in Male Wistar Rats. Insights in Biomed. 2017, 2:1.

Received: December 15, 2016; Accepted: February 01, 2017; Submitted: February 06, 2017

\section{Introduction}

In Nigeria, the folkloric uses of plant preparations for reproduction related purposes are well documented [1]. Herbal contraceptives are used because of affordability, ease of availability from local sources and less side effects [2]. Large number of plants used as abortifacient, contraceptive or sterility agents prevent implantation [3], suppress spermatogenesis [4], or are spermicidal [5].
Medicinal plants are used in Folkoric medicine in treatment of tumor ailment. Information obtained from traditional medicinal practioners in the South-Western Nigeria revealed that drinking decoctions of Paquetina nigrescens leaf, Moringa oleifera, Bradystegia eurocoma and Struchium sparganophora could significantly arrest the progression of tumor proliferation in patient [6]. 
Hymenocarda acida (euphorbiaceae) is a small brows tree or shrub with palatable foliage, widely distributed within the savannah region of Nigeria. The antimicrobial activities of $H$. acida leaves and roots have been reported [7]. There are literatures which have reported it to be anti-sickling [8], anti-ulcer [9], antidiarrhoea [10], and to possess anti-inflammatory activities [11]. Another study has investigated the antioxidant activity of the aqueous and methanolic extracts of $H$. acida. [12]. Phytochemical studies of $H$. acida showed the presence of saponins, tannins [13] flavonoids, flavonols, phenols, proanthocyanidins, steroids and triterpenoids. This study is designed to evaluate the spermatogenic and haematological effects of aqueous and ethanolic stem bark extracts of this Hymenocardia acida on Aluminium chlorideinduced toxicity in male wistar rats. The result obtained will help to know the possible effects of the plant extracts in human.

\section{Materials and Methods}

\section{Experimental animals}

Thirty healthy male albino wistar rats of weight 100-150 g were obtained from Animal house, Federal University Wukari, Taraba State. The animals were kept in clean cages (plastic bottom and wire mesh top) under room temperature, with 12 hours light and 12 hours dark cycle and were allowed to acclimatize for one week before the experiment. The animals were allowed free access to standard rat chow and water ad libitum.

\section{Plant specimen}

The stem bark of $H$. acida were collected within the premises of Federal University Wukari Taraba State. They were identified and authenticated in the Department of Biological Sciences, Federal University Wukari. The stem bark was rinsed, air dried at room temperature and pulverized using pestle and mortar. Water was used for the aqueous extract and stored in refrigerator, while exactly $270 \mathrm{~g}$ of the sample was weighed and dissolved in $1350 \mathrm{ml}$ of ethanol (for ethanolic extraction) for $48 \mathrm{hrs}$ after which it was filtered: first using a clean white sieving mesh and further with Whatman No. 1 filter paper. The ethanolic filtrate was concentrated using a thermostat water cabinet at $40^{\circ} \mathrm{C}$ for 7 days. The concentrated extracts were then transferred to air-tight containers, corked and preserved in the refrigerator at $4^{\circ} \mathrm{C}$ until required for the experiment.

\section{Preparation of aluminium chloride}

Exactly $2 \mathrm{~g}$ of Aluminium Chloride salt was weighed and dissolved in $5 \mathrm{ml}$ of distilled water. The solution was prepared daily. The Aluminium Chloride solution was administered $100 \mathrm{mg} / \mathrm{kg}$ bw of the rats.

\section{Experimental design}

The rats were distributed into six groups of five (5) rats each: Group 1 served as normal control: received only normal feed and water daily. Group 2 served as negative control (received only Alumimium Chloride: $100 \mathrm{mg} / \mathrm{kg}$ bw daily). Group 3 was administered Aluminium chloride + aqueous extract of Hymenocardia acida stem bark: The rats were administered with $100 \mathrm{mg} / \mathrm{kg}$ bw of the extracts one hour after administration of 100 $\mathrm{mg} / \mathrm{kg}$ bw of $\mathrm{AlCl}_{3}$. Group 4 was administered Aluminium chloride + ethanolic extract of Hymenocardia acida stem bark: The rats were administered with $100 \mathrm{mg} / \mathrm{kg}$ bw of the extracts one hour after administration of $100 \mathrm{mg} / \mathrm{kg}$ bw of $\mathrm{AlCl}_{3}$ Group 5: Received normal feed + aqueous extract of Hymenocardia acida stem bark bark daily, while group 6 received normal feed + ethanolic extract of Hymenocardia acida stem bark daily.

\section{Animal sacrifice and sample collection}

After the experiment, the animals were sacrificed under chloroform anesthesia. Blood samples were collected by cardiac puncture and the liver was harvested, weighed and rinsed in ice cold normal saline. The blood samples were collected in to EDTA collection tubes (for haematological analysis) and plain tubes for serum. The liver was homogenized using a standard laboratory mortar and pestle. The homogenate was centrifuged and the supernatant collected for Thiobabituric Acid Reactive Substances (TBARS) analysis.

\section{Determination of Thio-barbituric Acid Reactive Substances (TBARS)}

Thiobabituric Acid Reactive Substance formation was measured by using $10 \%$ trichloroacetic acid (TCA) solution and $0.6 \%$ of thiobabituric acid (TBA) solution. Exactly $50 \mu \mathrm{L}$ of tissue homogenate was added to a test tube containing $2 \mathrm{ml}$ of TCA, followed by $2 \mathrm{ml}$ of TBA and incubated at $80^{\circ} \mathrm{C}$ for 30 mins in a water bath. It was cooled immediately under ice and centrifuged at $3500 \mathrm{rpm}$ for 10 mins. The absorbance of the solution was read at $535 \mathrm{~nm}$ against a blank solution containing all except the sample. The TBARS was calculated using a molar extinction coefficient of $1.56 \times 105 \mathrm{M}^{-1} \mathrm{~cm}^{-1}$.

\section{Hormonal assay}

Luteinizing hormone (LH), Follicle stimulating hormone (FSH) and Testosterone were estimated using the method of Enzyme Linked Immunosorbent assay (ELISA)

\section{Determination of haematological parameters}

White blood cell (WBC) count, red blood cell (RBC) count, Haemoglobin $(\mathrm{Hb})$, Packed cell volume (PVC) and Platelet (PLT) were determined using Abacus 280 auto-haematology analyzer.

\section{Ethics}

All animals received humane care according to the criteria outlined in the Institution's Guide for the Care and Use of Laboratory Animals.

\section{Results}

\section{Thiobarbituric Acid Reactive Substance (TBARS)}

Results in Table 1 show the level of Thiobarbituric acid reactive substance in liver of the rats. The result show a significant $(p<0.05)$ increase in animals of negative control group when compared with normal control. There was also a significant change in group administered normal rats feed + aqueous extract and ethanolic extract of $\mathrm{H}$. acida when compared with normal control. There was a significant $(p<0.05)$ reduction of TBARS level in animals 
Table 1 Effect of aqueous and ethanolic extract of $\mathrm{H}$. acida on TBARS levels in liver of Aluminum chloride treated male rats.

\begin{tabular}{cc} 
Group & Conc. $(\mathrm{nmol} / \mathrm{mL})$ \\
\hline Normal Control & $0.05 \pm 0.06^{\mathrm{a}}$ \\
\hline Negative Control & $0.24 \pm 0.02^{\mathrm{d}}$ \\
\hline $\mathrm{AlCl}_{3}+$ H.A. Aq. & $0.09 \pm 0.05^{\mathrm{a}, \mathrm{b}, \mathrm{c}}$ \\
$\mathrm{AlCl}_{3}+$ H.A. Eth & $0.08 \pm 0.03^{\mathrm{a}, \mathrm{b}}$ \\
$\mathrm{N}$ + H.A Aq. & $0.11 \pm 0.02^{\mathrm{b}, \mathrm{c}}$ \\
N. + H.A Eth & $0.13 \pm 0.02^{\mathrm{c}}$
\end{tabular}

Note: Each value represents the mean of 5 rats \pm SD

Mean in the same column, having different letters of the alphabet are statistically significant $(p<0.05)$.

treated with $\mathrm{AlCl}_{3}+$ aqueous and $\mathrm{AlCl}_{3}+$ ethanolic extract of $\mathrm{H}$. acida when compared with the negative control.

\section{Hormonal assay}

Table 2 shows the result of hormonal assay in the male albino rats. The result shows that there was a significant $(p<0.05)$ decrease in luteinizing hormone (LH) and follicle stimulating hormone (FSH) in the negative control animals (intoxicated with aluminium chloride only) when compared with normal control group. The LH non-significant $(p>0.05)$ increased in normal rats administered the aqueous and ethanolic extract of $\mathrm{H}$. acida. There was no alteration in testosterone level of all groups when compared with normal control and negative control. There was a non-significant ( $p>0.05$ ) decrease in follicle stimulating hormone in animals treated $\mathrm{AlCl}_{3}+$ aqueous and $\mathrm{AlCl}_{3}$ +ethanolic extract, and also a non-significant ( $p>0.05$ ) decrease in luteinizing hormone in animals treated $\mathrm{AlCl}_{3}+$ ethanolic extract: when compared with the negative control.

\section{Haematological parameters}

Table 3 shows the result of the haematological parameters evaluated. There was a non-significant $(p>0.05)$ alterations of all the parameters in the negative control, when compared with the normal control. White blood cell (WBC) increased, while there was a decrease in haemoglobin ( $\mathrm{Hb})$, red blood cell (RBC) and platelet levels of rats induced with $\mathrm{AlCl}_{3}$. The administration of the plant extracts moderated most of these alteration, although some are not statistically significant.

\section{Discussion}

Aluminium chloride has been shown to affect spermatogenesis in experimental animals and humans which can lead to low sperm count, abnormal sperm morphology and poor semen quality [14]. Hymenocardia acida on the other hand has an antioxidant activity [12] and pro-oxidant activity [15]. The result of this study show that aluminum chloride did not cause significant $(p<0.05)$ difference in testosterone levels of the rats. This may be as a result of antioxidant capacity of Hymenocardia acida extract on Aluminum chloride-induced toxicity or may be that the plant extracts do not possess the ability to interfere in the processes involved in the production of testosterone.

The decrease in Luteinizing hormone of the negative control group when compared with normal control is in accordance with the previous studies [16] which reported that aluminium chloride contents in humans and animal testes, spermatozoa, blood and urine were associated with impaired sperm quality, viability and alternation in histology of testes, alternation in spermatogenesis, enhancement of free radicals and alternation in antioxidant enzymes. The decrease in LH that occurred in the group induced with aluminium chloride (negative control) may be due to oxidative damage to histo-archicture of hypothalamus caused by $\mathrm{AlCl}_{3}$ toxicity. There was an increase in the level of luteinizing hormone in animals treated with aqueous and ethanolic extracts of $H$. acida when compared with the negative control. The shows that the plant extracts could encourage the process involved in the synthesis of luteinizing hormone.

There was significant $(p<0.05)$ decrease in follicle stimulating hormone (FSH) in animals induced with $\mathrm{AlCl}_{3}$-toxicity (negative control) when compared with normal control. This may be due to interaction of $\mathrm{AlCl}_{3}$ with the anterior pituitary gland thereby resulting in oxidative damage to architecture of the anterior pituitary gland responsible for the production of follicle stimulating hormone (FSH) (glycoprotein hormone) and Luteinizing hormone. The increase in the groups treated with the aqueous and ethanolic extracts of the plant show that its chemical content may promote the effect of pituitary gland and the production of luteinizing hormone.

The result also show that $\mathrm{AlCl}_{3}$-toxicity caused significant $(\mathrm{p}<0.05)$ increase in the TBARS levels in liver of albino wistar rats (negative control). The increase of TBARS concentration in the liver can be a consequence of critical accumulation of $\mathrm{AlCl}_{3}$, thereby causing hepatic lipid peroxidation. This result is in agreement with previous studies $[17,18]$ that reported significant increase in TBARS levels of $\mathrm{AlCl}_{3}$ treated rats. However, treatment with the plant extracts show that the plant possesses the ability to ameliorate the negative effects caused by $\mathrm{AlCl}_{3}$-toxicity. This suggests that $H$. acida possess antioxidant properties.

Red blood cells (RBC) and haemoglobin $(\mathrm{Hb})$ are important in transporting respiratory gases. Administration of $\mathrm{AlCl}_{3}$ mildly altered some of the haematological parameters analyzed. This shows that $\mathrm{AlCl}_{3}$-toxicity could cause reduction of $\mathrm{Hb}$ and red blood cell count, and therefore could possibly induce anaemia. The effect of the stem bark extracts of $\mathrm{H}$. acida was able to moderate some of the haematological parameters altered by $\mathrm{AlCl}_{3}$. Platelets play important role in the process of haemostasis and its reduction might adversely affect thrombopoietin. The modulation of the platelet count following oral administration of $\mathrm{H}$. acida stem bark extract indicates that the extract may not cause any coagulation problem, but has the potential to enhance clotting and prevent haemorrhages.

\section{Conclusion}

This result of this study provides significant evidence for the oxidative damage caused by $\mathrm{AlCl}_{3}$ in Wistar rats using testosterone, follicle stimulating hormone (FSH), luteinizing hormone, TBARS and some haematological parameters (WBC, RBC, PLT, PCV and $\mathrm{Hb}$ ) as biomarkers. It is therefore, concluded that $\mathrm{AlCl}_{3}$ toxicity causes alterations of $\mathrm{LH}, \mathrm{FSH}$ and TBARS, but aqueous and ethanolic stem bark extracts of $H$. acida may possibly ameliorate the alteration. Also, $\mathrm{AlCl}_{3}$-toxicity mildly influences the synthesis of certain 
Table 2 The effect of aluminium chloride on male wistar rats treated with aqueous and ethanolic extract of $H$. acida stem bark.

\begin{tabular}{|c|c|c|c|}
\hline Group & LH & FSH & Testosterone \\
\hline Normal control & $0.04 \pm 0.01^{\mathrm{a}}$ & $8.00 \pm 0.70^{a}$ & $20.00 \pm 0.00^{a}$ \\
\hline Negative control & $0.03 \pm 0.01^{\mathrm{a}}$ & $6.08 \pm 0.36^{b}$ & $20.00 \pm 0.00^{\mathrm{a}}$ \\
\hline $\mathrm{AlCl}_{3}+\mathrm{H} \cdot \mathrm{A}$ Aq. & $0.03 \pm 0.01^{\mathrm{a}}$ & $6.10 \pm 1.37^{b}$ & $20.00 \pm 0.00^{\mathrm{a}}$ \\
\hline $\mathrm{AlCl}_{3}+\mathrm{H} \cdot \mathrm{A}$ Eth. & $0.04 \pm 0.01^{\mathrm{a}}$ & $6.20 \pm 1.37^{b}$ & $20.00 \pm 0.00^{a}$ \\
\hline Normal + H.A Aq. & $0.05 \pm 0.02^{\mathrm{a}}$ & $7.90 \pm 0.20^{\mathrm{a}}$ & $20.00 \pm 0.00^{\mathrm{a}}$ \\
\hline Normal+ H.A Eth. & $0.06 \pm 0.02^{\mathrm{a}}$ & $7.80 \pm 0.85^{a}$ & $20.00 \pm 0.00^{a}$ \\
\hline
\end{tabular}

Note: Each value represents the mean of 5 rats \pm SD

Mean values in the same column, having different superscripts are statistically significant $(p<0.05)$.

Table 3 Effect of aqueous and ethanolic extract of $H$. acida on haematological parameters

\begin{tabular}{|c|c|c|c|c|c|}
\hline Group & WBC $\left(\times 10^{9} / L\right)$ & $\operatorname{RBC}\left(\times 10^{6} / \mu \mathrm{L}\right)$ & $\mathrm{Hb}(\mathrm{g} / \mathrm{dL})$ & PCV (\%) & 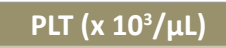 \\
\hline Normal Control & $8.55 \pm 6.04^{\mathrm{a}}$ & $6.90 \pm 1.04^{\mathrm{a}}$ & $13.75 \pm 2.69^{d}$ & $47.33 \pm 6.65^{c, d}$ & $410.50 \pm 65.17^{c, d}$ \\
\hline Negative Control & $8.78 \pm 5.69^{a}$ & $5.96 \pm 1.37^{a}$ & $12.60 \pm 0.72^{c, d}$ & $49.78 \pm 4.83^{d}$ & $229.25 \pm 20.21^{\mathrm{a}}$ \\
\hline $\mathrm{AlCl}_{3}+\mathrm{H} \cdot \mathrm{A} \cdot \mathrm{Aq}$ & $6.35 \pm 1.82^{\mathrm{a}}$ & $7.42 \pm 0.25^{a, b}$ & $12.98 \pm 0.43^{c, d}$ & $48.35 \pm 1.51^{c, d}$ & $463.75 \pm 16.54^{d}$ \\
\hline $\mathrm{AlCl}_{3}+\mathrm{H} \cdot \mathrm{A}$ Eth & $4.43 \pm 1.33^{\mathrm{a}}$ & $6.67 \pm 1.42^{\mathrm{a}}$ & $13.03 \pm 1.15^{c, d}$ & $39.43 \pm 10.67^{b, c}$ & $282.50 \pm 26.30^{a, c}$ \\
\hline N. + HA Aq & $8.19 \pm 1.80^{\mathrm{a}}$ & $6.18 \pm 0.13^{a}$ & $10.95 \pm 0.61^{b, c, d}$ & $34.21 \pm 1.74^{\mathrm{a}, \mathrm{b}}$ & $349.75 \pm 77.75^{b, c}$ \\
\hline N. + H.A Eth & $9.88 \pm 2.65^{a}$ & $9.46 \pm 2.66^{b}$ & $11.25 \pm 1.15^{b, c, d}$ & $32.63 \pm 1.96^{a, b}$ & $398.00 \pm 44.93^{c, d}$ \\
\hline
\end{tabular}

Each value represents the mean of 5 rats \pm SD

Mean values in the same column, having different superscripts are statistically significant $(p<0.05)$.

haematological indices, but the extracts may modulate some of this interference. Further research should need to be carried out to understand the structural and functional relationship in these extracts and the possible mechanism of action. 


\section{References}

1 Akaneme $\mathrm{Fl}$ (2008) Identification and preliminary phytochemical analysis of herbs that can arrest threatened miscarriage in Orba and Nsukka towns of Enugu state. Afri J Biotechnol 7(1): 6-11.

2 Gupta RS, Kachawa JB, Chaudhaury R (2004) Antifertility effects of methanolic pod extract of Abizzia lebbeck. Asian J Androl 6: 155-159.

3 Vasudeva N, Sharma SK (2007) Estrogenic and pregnancy interceptory effects of Achyranthes aspera Linn. root. Afr J Trad Compl Altern Med 4(1): 7-11.

4 Raji Y, Akinsomisoye OS, Salman TM (2005) Antispermatogenic activity of Morinda lucida extract in male rats. Asian J Androl 7(4): 405-441.

5 Paul D, Bera S, Jana D, Maiti R, Ghosh D (2006) In vitro determination of the contraceptive activity of a composite extract of Achyranthes aspera and Stephania hernandifolia on human sperm. Contraception 73(3): 284-288.

6 Soladoye MO, Amusa NA, Chukwuma EC (2010) Ethnobotanical survey of anti-cancer plants in Ogun State, Nigeria.

7 Mann A, Amupitan JO, Ogewale AO, Okogun JI, Ibrahim K, et al. (2008) Evaluation of in vitro antimycobacterial activity of Nigerian plants used for treatment of respiratory diseases. African J Biotchnol 7(11): 1630-1636.

8 Mpiana PT, Tshibanga DST, Shetonde OM, Ngbolua KN (2007) In vitro anti-drepanoytary activity (anti-sickle cell anaemia) of some Congolese plants. Pytomed 14: 192-195.

9 Ukwe CV (2004) Evaluation of the anticancer activity of aqueous stem bark extract of Hymenocardia acida. Nig J Pharm Res 3(1): 8-89.
10 Tona L, Kambu K, Masia K, Cimanga R, Asperse S, et al. (1999) Biological screening of raditional preparations from some medicinal plants used as anti-diahoeal in Kinshasha congo. Phytomed 6(1): 59 -66 .

11 Muanza DN, Euler KL, Williams L, Newman DS (1995) Screening for anti-tumour and anti-HIV activities of nine medicinal plants from Zaire Int J Phamacol 33(2): 98-106.

12 Sofidiya MO, Odukoya OA, Afolayan AJ, Familoni OB (2009) Phenolic contents, antioxidant and antibacterial activities of Hymenocardia acida. J Nat prod Res 23: 168-177.

13 Schmelzer GH (2008) Hymenocardia acida Tul: Medicinal plants/ plants medicinal 1. [CD-Rom]. PROTA, Waganingen, The Netherlands 11: 1 .

14 Pizent B, Tariba S, Zivkovic T (2012) Reproductive toxicity of metals in men. Archives of Industrial Hygiene and Toxicology 63: 35-46.

15 Abu AH, Uchendu CN (2010) Anti-spermatogenic effects of aqueous ethanolic extract of Hymenocardia acida sterm bark in Wistar rats. Journal of Medicinal Plant Research 4(23): 2495-2502.

16 Reusche E, lindner B, Arnholdt H (1994) Widespread Aluminium deposition in Extracerebral organ systems of patients with dialysisassociated encephalopathy. Virchows arch 424: 105-112.

17 Hala AH, Inas ZA, Gehan M (2010) Grape seed extract alleviate reproductive toxicity cause by Aluminium chloride male rats. Journal of American Science 6(12): 1201-1204.

18 Yakubu OE, Nwodo OFC, Udeh SMC, Abdulrahman M (2016) The effects of aqueous and ethanolic extracts of Vitex doniana leaf on postprandial blood sugar concentration in wister rats. International Journal of Biochemistry and Research Review 11(3): 1-7. 